3. The macular figure, as Mr. Gunn stated, is caused by tension lines centred at the fovea, the greatest stress being just beneath the intima.

4. The phagocytes of the retina consist of several kinds, as follows: (1) Wander-cells; ( (2) connective tissue corpuscles; (3) epitheloid corpuscles of the nerve fibre layer; (4) epithelioid corpuscles of the outer granule layer-the two latter varieties being in close relation to the supporting fibres of Müller.

REFERENCES

1 Babinski et Chaillous : Société Française d'Ophtalmologie, 1907.

2 Bruns : Neurologisches Centralblatt, 1898, 8. 781-2.

3 Chaillous : Recueil d'Ophtalmologie, 1908, T. 30, p. 291.

4 Charles: American Journal of Ophthalmology, 1909, vol. xxvi, p. 161 5 Cushing and Bordley: Bulletin of the Johns Hopkins Hospital, 1909 , vol. $\mathrm{xx}$, p. 95 .

Cushing and Bordley : Transactions of the American Medical Association, vol. lii, p. 353 .

De Schweinitz and Holloway: The Operative Treatment of Papill dema, The Transactions of the College of Physicians of Philadelphia, 1908, vol. Xxx, p. 140

(insesonderes die sogenannte gungspapille, etc. Jena, 1887.

9 Dimmer: Archiv fiir Ophthalmologie, 1907, Bd. 65, S. 544

10 Dimmer

11 Elschnig : Archiv für Ophthalmologie, 1895, Bd. 41, Abth. 2, p. 179. Wiener klinische Rundschau, 1905, No.

12 Frost, Adams: The Fundus Oculi, etc. 1896.

18 Gowers: Lancet, July 10th, 1909 .

14 Gunn: BRITISH MEDICAL JodRNAL, 1907, p. 1126.

15 Gunn: Transactions of the Internatijnal Ophthalmic Congress (Edinburgh) 1894

16 Henderson (Thomson): British Medical Jodrnal, 1909, vol. ii,

p. 878 .

17 v. Hippel : Archiv für Ophthalmolngie, 1908, Bd. 69, Heft 2, p. 290

18 Horsley: Le Mercredi Médical, August 27th, 1890, p. 415.

19 Horsley: British MedTCAL JouRNAL, 3890, vol. ii, p. 1286.

20 Horsley : Ibid., 1893, December 23rd, p. 1366.

21 Horsley: Clinical Journal, February 13th, 1895.

22 Horsley : BrITISH MEDICAI, JoURNAL, 1906, p. 412.

23 Horsley : Transactions of the Ophthalmological Society of the United

Kingdom, 1908, vol. Xxviii, p. 136

Horsley: Ophthalmosccpe, 1908, September.

25 Horsley: BRITISH Medical JodkNAL, 1909, September 25th, p. 877.

(Abstract of present paper.)

26 Iwanoff : Archiv tiir Ophthalmologie, Band 15, Abth. 2, S. 88.

27 . Krüdener : A rchiv fiir Ophthalmologie, 1907, Bd. 65, S. 69.

(16, S. 265 . Bd.

(29 Merigina)

paper).

80 Manz : Archiv fiir Psychiatrie. 1889, Bd. 20, S. 567.

31 Marchand, F., jun. : Ziegler's Beiträge, 1909.

Martin, Middelton: The Localizing Value of Optic Neuritis in

${ }_{88}$ Nuel : Les névrites optiques. Le Névraxe, 1901, vol. iii, p. 1.
${ }^{8}$.

34 Parinaud: Etude sur la Névrite Optique. Paris: Baillière et Fils. 1877.

35 Parsons: Pathology of the Eye, 1908, vol. iv, p. 1249 et seq.

36 Paton: Transactions of the Ophthalmological Society of the United Kingdom, 1905, vol. Xxv.

${ }^{37}$ Paton: Ibjd., 1908, vol. xxviii (this paper is of cases observed in the National Hospital during 1906-71

88 Paton: Brain, 1908, (No. 22 much extended and reprinted with dditional tables)

${ }^{89}$ Rowlands: Guy's Hospital Gazette, 1898, Nov. 5, and Medical Press, 1909 , p. 14.

Saenger. For full list of papers on the subject see v. Hippel's paper, p. 353 .

41 Schmidt: Archiv für Ophthalmologie. Bd. 15, Abth. 2, S. 193

42 Stewart, Purves: The Diagnosis of Nervous Diseases, 1908, p. 414 419.

Swanzy : Eye Diseases and Eye Symptoms in their Relations to

vol. iv, p. 539. . 189.

Archiv für Ophthalmologie, 1909, Band 69, Heft 3, S. 391

Wilbrand u. Saenger: Neurologie des Auges, Bd. 4, pp. 310-322.

47 Williamson : Brain, 1896, vol. xix, p. 346

\section{MINER'S NYSTAGMUS.*}

By T. HARRISON BUTLER, M.D.OxoN. HONORART OPHTHALMIC SURGEON TO THE COVENTRY AND WARWICKSHIRE HOSPITAL.

IN all colliery centres miner's nystagmus is a very common disease. It is scheduled under the Act of 1907 as a condition for which a miner may claim compensa. tion, and so a knowledge of its leading characteristics is essential to all medical men practising in such a district. The average ophthalmic textbook devotes only a few lines to the affection, and even the meagre information given is apt to be somewhat dogmatic and inaccurate.

The symptoms in a severe case are very characteristic. The eyes oscillate violently, the eyelids twitch, and the man appears to be, and often is, in a state of great nervous agitation. When his visual acuity is tested with the types

* Read t: the Coventry Division of the British Medical Association. it will generally be found to be as low as one-tenth of the normal. He is quite unable to read or to continue at his work, and will frequently complain that he cannot see his way about in the dark. But such a violent attack is uncommon, and it will be, therefore, proper to consider in detail the more usual manifestations of the affection.

The history is typical. The miner has almost invariably worked some years in the pit, and has in most cases been a "holer," one who lies on his side and undercuts the seam of coal. He first notices that at the end of a day's work the lights begin to "dance." They may dance vertically, horizontally, or in a circular fashion like a Catherine-wheel. He can for a time overcome this oscillation by looking down and resting his eyes. Soon, however, the dancing commences earlier in the day, and he more frequently has to "steady" his eyes, and finally the lights begin to dance as soon as he enters the mine, and work becomes impossible. At this period the subjective sense of movement may cause vertigo.

In the early stages of miner's nystagmus the sufferer is free from trouble when he leaves the pit, but as the disease progresses nystagmus is present when it grows dark and the street lamps are lighted. Eventually nystagmus is always noticed, even in daylight.

At the beginning of the case nystagmus only commences when the eyes are considerably raised, then it appears as soon as the gaze rises above the normal plane, and later it only ceases when the sobject looks down. In fact, the severity of the attack can be accurately gauged by the angle above or below the primary position at which nystagmus can be elicited. The position of the head, however, has notbing whatever to do with the matter; nystagmus can be demonstrated just as easily in the supine posture if the eyes be directed towards the brows as it can in the erect. Peters is quite incorrect when he states that nystagmus ceases if the head be thrown back. It does so in many cases if the patient looks at the same object, but if he move his eyes back pari passu with his head nystagmus does not cease.

In a slight case, or one which is in process of cure, it may often be impossible to detect any nystagmus by. simply raising the eyes. Reid has taught us that if we rotate the patient several times, until he is a little giddy, and then direct his eyes to the ceiling, nystagmus may appear. If we can produce no nystagmus by this method it is safe to assume, either that the case is not one of nystagmus, or that it has been cured.

The direction of the nystagmus may be vertical, horizontal, or circular. In my own practice the vertical variety has been rare. One eye may have a different kind of nystagmus from the other.

Hemeralopia may be present. Court found it in 127. cases out of 164 ; Dransart detected it in 5 per cent. of his patients. Romiée states that he has never seen this symptom, although he has examined several thousand individuals. My own experience has been that night blindness is undoubtedly a symptom of the disease. Probably. at least 25 per cent. of all cases are unable to see in the dusk.

Visual acuity is unaffected when the eyes are at rest. If the types be placed on the floor level and the miner stand upon a chair, he may read the last line; if he sit down and the types be hung on the wall, he may fail to read the top line.

I shall now present my case to you :

T. R., aged 45, was a miner in the Newãigate Colliery, a lamp mine; had been a miner all his life.

About six months ago he began to notice that the lamps were dancing up and down. He had to sit down and "steady" his eyes. Three months ago, when he was examining the roof, a piece of coal fell upon his nose and cut his face. Had he nos had violent nystagmus he would have seen that a large fragment was loose and would have avoided it. After the accident the nystagmus got much worse. He sees very badly at night, not only becanse everything is in motion, but because there is a " sort of mist before his ezes." He sees a little better if he looks down, but not so well as his mates do. In fact, he has slight hemeralopia.

Condition when First Seen.-Violent nystagmus and twitching of lids. Vision $=\frac{8}{80}$. Advised to give up his work underground entirely and permanently.

Condition a Month Later. -The eyes were normally at rest, but if he looked at an object fxedly for a few seconds his eyelids began to blink and twitch violently and he looked away as though shielding his eyes from a dazzling electric arc. As soon 
as he looked upwards violent twitching and vertical nystagmus commenced.

$$
\begin{aligned}
& \text { R.V. }=\frac{8}{80} \frac{-3.5}{-2, \text { axis horizontal. }}=\frac{8}{6} \\
& \text { L.V. }=\frac{6}{60} \mathrm{c} \frac{-3}{-1, \text { axis horizontal. }}
\end{aligned}
$$

The fundus was normal but could only be seen with great diff sulty on account of the twitching of the lids. He was unable to cesd even when he looked down.

The patient subsequently improved considersbly, but he cannot do any work, for as soon as he looks fixedly at an object the oscillations commence.

This is a most instructive case. In the first place, it shows the classical symptoms-symptoms which have been ameliorated but not cured by rest. Before the Compensation Act this miner would have been discharged and left to starve; now the colliery responsible for his disease has to keep him!

Again, the nystagmus conduced to an accident and the accident aggravated the disease. Dransart and Romiée lhave shown conclusively that nystagmus often starts after an accident, and that it is frequently aggravated by an accident.

It is worthy of note that in this case the nervous agitation becomes evident as soon as the eyes are fixed upon an object. This has an important bearing upon the etiology of the disease. An analogous symptom is the inability of many sufferers to read, even though they have good vision and have no nystagmus in the reading position.

The etiology of the complaint is very obscure. The textbooks say that it is strictly comparable to scrivener's palsy, due to cramp of the elevator muscles of the eye. This is the theory enunciated by Snell, by Nieden, and by Dransart; it was for long accepted without criticism or challenge, and has been copied from book to book, rather as a proved fact than a hypothesis. To be brief, the view that the miner is always straining his eyes upwards, producing muscle fatigue, which results in nystagmus, does not account for the facts. First, the miner does not strain his eyes upwards; like other sensible mortals he makes himself comfortable and moves his head, not his ejes. Secondly, there is no proof that any muscle fatigue exists, and conclusive proof that it does not; and, finally, if muscle fatigue did exist, it would produce a tetanic and not a clonic spasm.

Nystagmus is essentially a disease of the collier; it is not found in metal mines, where men work under similar conditions to those obtaining in coal mines, but with one great difference-the metal mine is not bounded by glittering black walls.

The disease was first described at the time when the Dary lamp was introduced into mines, and as soon as the use of safety lamps was enforced by law it became very frequent-that is to say, as soon as the illumination of the miner's candle, which gives 0.5 candle power, was replaced by that of the Davy lamp with its feeble glimmer of 0.28 candle power, cases of nystagmus became increasingly frequent. The miner's lamp has been improved now, and the disease is much less common than it was. The ordinary lamp used to-day has a candle power when clean of 0.44 , but as it gets covered with dust and the wick chars, its light falls off rapidly.

But darkness cannot be the sole cause of nystagmus. The employees in photographic factories who work for hours in absolute darkness, do not contract nystagmus, nor do boiler makers and other artisans who work by seeble light.

The only theory which can explain the disease is that suggested by Reid of Nottingham and Nuel in Belgium. It is a disordered cerebration, a defect in the brain, not of the eje muscles. It is produced by the peculiar work of the miner, long-continued rhythmic movements of the pick in comparative darkness. I have given the facts and reasoning which lead to this conclusion in greater detail in an article which I contributed to the Ophthalmoscope for August 1909. There also will be found the references to the various papers on the subject.

Snell attempted to show that compositors and other workmen do at times get occupational nystagmus, but a critical examination of his cases will lead to the conclusion that these men did not suffer from true miner's nystagmus; this disease always was and still is the special disease of the colliery.
The treatment is simple. The miner must leave the mine, and must not return to it.

The prognosis must be guarded. Many cases recover completely, but on the other hand some never entirely lose their symptoms. In any case, no miner who bas once suffered from the disease must ever return to work underground.

\section{A CASE OF MUSCULAR DYSTROPHY (ERB'S JUVENILE FORM) OCCURBING IN AN ADULT.}

By H. L. McKISACK, M.D., M.R.C.P., PHYSICIAN TO THE ROYAL VICTORIA HOSPITAL, BELFAST.

THE premature death of certain selected muscles, which seems to constitute this disease, occurs without regard to the position of the trophic centres of the respective muscles in the cord. In the segments of the spinal cord groups of actions of muscles are represented rather than groups of muscles themselves; for example, elevation with abduction of the arm are accomplished by the trapezius, deltoid, and supraspinatus, these muscles being chiefly innervated from the fifth cervical segment. In the following case the absence of trophic influence of the segmental centres may be observed, only one of the muscles involved in elevation and abduction of the arm being atrophied.

A "plater" in a ship-building yard, aged 28, had been accustomed to severe muscular exertion, particularly of the arms and back. In spite of careful inquiry, no instance of a similar affection can be discovered among his relatives, past or present. He was a totel absteiner and had bad no serious previous illnesses except a suppurating inguinal gland, which
he attributed to an injury; he denied haviug had any venereal disease.

\section{disease.}

About two years before admission he noticed some weakness of his arms, and soon afterwards observed that his neck seemed smaller than before. These defects steadily progressed until his condition on admission to hospital on October 13th, 1909, had become as follows:

The mental faculties and the sensory apparatus are unchanged; the pupil reflexes are normal; the left knee-jerk is brisk, while the right is defective, and the wrist-jerks are absent; the fundus oculi is normal; the blood shows a positive Wassermann reaction. In the muscles of the arms and shoulders atrophy and weakness are to be found. I have drawn up a list of the muscles affected in tabular form, showing the segments of the cord from which the nerves supplying the dices sake some unaffected muscles connected with the same

\begin{tabular}{|c|c|c|c|}
\hline \multicolumn{2}{|c|}{$\begin{array}{l}\text { Segment of } \\
\text { Spinal Cord. }\end{array}$} & Muscles. & Condition. \\
\hline Cervical & 2 to $5 \ldots$ & $\begin{array}{lllll}\text { Trapezius... } & \ldots & \ldots & \ldots & \ldots\end{array}$ & $\begin{array}{l}\text { Atrophied (except } \\
\text { right upper } \\
\text { fibres). }\end{array}$ \\
\hline 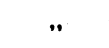 & 4 and 5 & $\begin{array}{lllll}\text { Rhomboids } & \ldots & \ldots & \ldots & \ldots\end{array}$ & Atrophied. \\
\hline " & 5 and 6 & $\begin{array}{l}\text { Deltoid, supraspinatus, and infra- } \\
\text { spinatus }\end{array}$ & $\begin{array}{l}\text { Normal (possibly } \\
\text { hypertrophied). }\end{array}$ \\
\hline " & 5 to $7 . .$. & Berratus magnus and biceps $\quad \ldots$ & Atrophied. \\
\hline$"$ & $", \cdots$ & $\begin{array}{l}\text { Pectoralis major (clavicular por- } \\
\text { tion) }\end{array}$ & Normal. \\
\hline$"$ & $7 \quad \cdots$ & $\begin{array}{llll}\text { Latissimus dorsi } & \ldots & \ldots & \ldots\end{array}$ & Atrophied. \\
\hline 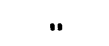 & 4 to $8 . .$. & Triceps and supinator longus $\quad \ldots$ & Atrophied. \\
\hline$"$ & $" \quad " .$. & $\begin{array}{l}\text { Other forearm and hand muscles } \\
\text { supplied by musculo-spiral and } \\
\text { median nervas }\end{array}$ & Normal. \\
\hline Dorsal 1 & $8\} \cdots$ & $\begin{array}{l}\text { Forearm and hand muscles sup- } \\
\text { plied by ulnar nerve }\end{array}$ & Normal. \\
\hline $\begin{array}{l}\text { Cervical } \\
\text { Dorsal } 1\end{array}$ & $8\}$ & Pectoralis major (sternal portion) & Atrophied. \\
\hline
\end{tabular}
segments.

The condition of the muscles above mentioned exists on both sides of the body, except in the case of the trapezius.

There are no fibrillary twitchings. The condition of the muscles has been verified by Dr. J. C. Rankin, who finds 